\title{
Supply-side Structural Reform of Cultivating Higher Vocational Talents of Tourism in the Context of Region-based Tourism
}

\author{
Chen Wei \\ Chengdu Polytechnic \\ Chengdu Sichuan \\ 8269270@qq.com
}

\begin{abstract}
At present, the concept and mode of universal tourism is rooted in the restricting and upgrading of the tourist industry. In the background of universal tourism, the tourist industry urgent needs a great many talents of tourism. However, high vocational school as cultivate tourism talents is the core force in talent supply. And it is the main output channel about high-level talents with technical skills. However, higher tourism personnel training have already fallen behind the tourism industry transition. And high vocational school exists mismatching and the structural discrepancy between supply side and demand side. In fact, it reflects phenomenon that higher tourism personnel training misfits tourism industrial structure and needs reform. Therefore, on the basis of analyzing the features of demands for tourism talents as well as the problem of higher vocational tourism talents cultivation, this article proposed the new measures for supply-side structural reform of cultivating higher vocational tourism talents in terms of thinking, type and mode.
\end{abstract}

Keywords-region-based tourism; tourism talents cultivation; feature; problem; measure

\section{INTRODUCTION}

In 2016, Li Jinzao, the director of China National Tourism Administration, pointed out in the National Tourism Conference that: Chinese tourism should transform from "spots tourism" to "region-based tourism", and apply the concept and mode of "region-based tourism" to transformation and upgrading of tourist industry. The tourism vocational education in higher vocational colleges cultivating tourism talents is not only the backbone force of talents supply, but also the primary output channel for high-level skilled talents. In the context of region-based tourism, tourist industry is badly in need of a large number of tourism talents, and higher vocational tourism education has been unable to keep pace with the development of tourism industry. At present, graduates can't find appropriate job, while enterprises can't find proper talents. There is mismatching and structural contradiction between supply and demand, reflecting the inconformity between tourism talents cultivation structure and tourism industrial structure, which is a prominent problem in urgent need of reform.

Meanwhile, in November 2015, President Xi proposes "supply-side structural reform" which is a significant strategic deployment and innovation. Accordingly, this becomes the logical starting point for talents cultivation reform in higher vocational education, and proposes new historical demands for higher vocational talents cultivation [1]. Under the background of region-based tourism, based on the investigation of the features of talents demands in tourism industry, the paper studied the supply-side structural reform in higher vocational tourism talents cultivation.

\section{ANALYSIS ON THE FEATURES OF TALENTS DEMAND IN TOURISM INDUSTRY IN THE CONTEXT OF REGION-BASED TOURISM}

Region-based tourism means that in the certain region, taking the tourist industry as the competitive industry, the economic and social resources in the region, especially tourism resources, relevant industries, ecological environment, public service, system and mechanism, policies and regulations, and quality of civilization, are completely and systematically optimized and improved, so as to realize organic integration of regional resources, integrative development of industries, and co-construction and sharing of the society, and achieve the concept and mode of economic and social coordinated development which is the coordinated development of regions led and promoted by tourism [2]. The core of the concept includes new concept of development, cooperation, resource, product, market and service. The implementation of the concept needs the participation of the whole society, especially practitioners in tourist industry. As a result, the tourism major in higher vocational colleges which input a great deal of practitioners for tourist industry should match with the core of the concept of region-based tourism in terms of talents cultivation.

Region-based tourism itself means the expansion of the concept of tourism as well as the diversification of tourist industry condition, that is, more new concepts and ideas are integrated into more fields to gather more strength, fully play the role of fusion agent of tourism, promote integrative development of "tourism plus", and abut enormous tourism consumption demands. Accordingly, different requirements for practitioners in tourist industry are proposed to adapt to industrial development. 


\section{A. Innovative talents sensitive to the market and daring to innovate industrial form}

At present, in China, economic and social development is at the key state of transforming from traditional resource-oriented economy to innovation-driven economy. In the economic and social development reform [3], tourist industry is the pillar of national economy. The state vigorously develops service industry, and creates many opportunities in the era of "Internet plus", especially, in the context of region-based tourism, the people sensitive to the market and daring to innovate industrial forms will success in the market. As a comprehensive industry, innovative talents with innovative quality, will, observation, thinking and practice are necessary and will become the key of development momentum of tourist industry in the future.

\section{B. “Craftsman" with professional, dedicated, concentrated and craftsman's spirit \\ "Craftsman's spirit" is the significant driving force of} supply-side structural reform of China, and the professional ethics, ability and quality are important expressions of brand image of industries and enterprises. In the face of constantly rising industrial conditions and forms, the only rule of coping with shifting events by sticking to a fundamental principle is the inheritance of "craftsman's spirit" with the connotation of dedication, improvement, concentration and innovation. Therefore, under the background of region-based tourism, tourist industry is more badly in need of the "craftsman" talents with the spirit to serve tourism, so as to greatly improve the satisfaction of consumers, increase the service quality of tourist industry, and promote further development of the industry.

\section{Trans-disciplinary talents with "borderless" integration ability}

At present, in the overall context of diversified tourism consumption, innovative tourism elements, independent tourism choice, region-based tourism development, as well as "tourism plus" and "Internet plus", the border of tourist industry has been greatly expanded, and new value growth point has been created by integrating information technology and other industries into tourism. Accordingly, tourism industry is badly in need of tourism talents who have innovative thinking and can provide personal service. This requires tourism talents have the ability of research information and integrate information. At the same time, they also can master multi-disciplinary knowledge expect tour specialty. For example, tourism and nourishing of life, tourism and sports etc. only in this way, can they provide more professional service to tourist. As a result, the development of tourism needs the transdisciplinary talents with open thinking, active mind, strong desire for new things and different fields, and integrative awareness and ability.

\section{PROBLEMS ABOUT TOURISM TALENTS CULTIVATION IN HIGHER VOCATIONAL COLLEGES}

At present, the contradiction between talents in higher vocational colleges and employment requirements of enterprises becomes more and more serious. Students are unable to meet the requirements of positions provided by enterprises, and the students lack vocational practical skills and professional quality. As the primary channel outputting tourism talents, higher vocational colleges can't keep pace with the development and changes of tourist industry in terms of talents cultivation, and there are mismatching and structural contradiction between supply-side and demand-side. Moreover, it does not conform to the double positioning (strategic pillar of national economy and modern service industry that people are more satisfied with) of tourist industry. Now the problems about tourism talents cultivation in higher vocational colleges are analyzed as follows:

\section{A. Lack of high-end vocational tourism talents cultivation}

Tourism vocational education should match with industrial development. At present, high-end tourism consumption and individual and customized tourism become more and more popular. However, at present, cultivation of higher vocational tourism talents still focuses on grasping and training low-end technical points, and the cultivation mode is single. The teaching program and talents cultivation mode have not been adjusted according to "Internet plus", intelligent big data and industrial reform, leading to lack of the high-end tourism talents and talents with "craftsman's spirit" and high-level skill who are the scarcest talents of tourism industry in the future.

\section{B. Tourism talents cultivation program of higher vocational colleges can't keep pace with the changes of new industrial conditions and fields}

Tourism talents cultivation program of higher vocational colleges including major construction and courses offered fall behind the fast changing trend of tourist industry, and the matching degree and adaptability between teaching program and talents needed by the industry are lower. Relevant courses emphasize professional knowledge and ignore practical skills, resulting in narrow scope of knowledge of students and poor practical ability, lack of adaptability to changes and ability of innovation, which can't adapt to the new requirements of region-base tourism [4]. However, it is difficult to adjust the talents cultivation program in the short time, therefore, the talents cultivated based on the original teaching program can't be competent for and adapt to the industrial trend and vocational demands as well as the industrial change in the new industrial condition, and the quality of the talents is not high. As a result, the talents in the new field and industrial condition are insufficient.

\section{Higher vocational tourism talents lack integrative awareness and trans-disciplinary ability}

With the prolongation of knowledge that tourism combines others and development of tourism internationalization, we require tourism talent can master interdisciplinary knowledge and develop in the direction of mixed mode. The tourism talents cultivation in higher vocational colleges basically emphasizes mastering and proficiency of practical operation skills, and ignores the cultivation of integrative awareness of students. It is limited to the field of the major, still focuses on traditional cultivation mode, lacks discussion and practice of innovative talents cultivation mode, therefore, the students lack trans-disciplinary awareness and ability which are necessary 
for tourist industry in the future. In the context of region-based tourism, many regions lacking tourism resources are intensifying their efforts to develop tourist industry, and the ability of creating culture is very important and requires the integrative awareness and ability.

\section{MEASURES FOR SUPPLY-SIDE STRUCTURAL REFORM OF HIGHER VOCATIONAL TOURISM TALENTS IN THE CONTEXT OF REGION-BASED TOURISM}

In order to adapt to the new concept of region-based coconstruction, development and sharing of region-based tourism, and accelerate the supply-side structural reform of tourism vocational education, cultivating the high-skill talents needed by tourism development will become the core element of promoting economic development and transformation. Therefore, supply-side structural reform of tourism talents cultivation in higher vocational colleges is imperative. Although the structure of higher vocational tourism talents cultivation is improved, with the increasing of practitioner of tourist industry, there will be more and more problems. The tourism vocational education in China is later than that in foreign countries, and there are many problems about the education system and curriculum in the present development trend and change of tourist industry. Besides, supply-side structural reform is the necessary choice to adapt to the "new industrial condition", therefore, aiming at the above-mentioned problems about supply-side of talents cultivation, the following measures are proposed.

\section{A. Transform employment-oriented cultivation thinking to vocation-oriented training thought}

At present, higher vocational tourism talents is still directed by employment. In fact, cultivating the high-skill talents adaptive to the development of tourist industry in the future should transform the employment-oriented concept to vocation-oriented thought, and optimize supply layer so as to cultivate vocational talents rather than employers. The transformation of cultivation thought is based on the demands of tourism enterprises for talents, such as talents with comprehensive professional quality, good integrative ability, excellent vocational skill and practical experience. Meanwhile, the core of vocation-oriented concept is to cultivate the social evolution force of students, including social curiosity, expectation for social progress, quality of social members and social resilience.

Vocation-oriented cultivation thinking not only emphasizes vocational ability, but also highlights the cultivation of craftsman's spirit of high-end skilled talents cultivated by higher vocational colleges. Cultivating craftsman's spirit can make students form the value orientation of reverence for profession and pursuit of perfection [5]. Since cultivation craftsman's spirit should actively adjust the professional curriculum setting of higher vocation colleges, it is necessary to closely integrate special course with market demands, change the "speed-up" and "blundering" psychology and thinking in education [6], focus on "slow-cooking" rather than "quick-boiling", penetrate craftsman's spirit to daily education system, cultivate craftsman's spirit according to teaching program in daily teaching, so as to internalize the craftsman's spirit of constantly striving for perfection, paying attention to details as well as specialty and dedication, and cultivate "craftsman" talents.

\section{B. Cultivate inter-disciplinary talents under the thought of "tourism plus"}

An important principle of region-based tourism is overall integration and coordinated sharing, namely, adopting the mode driven by overall coordination and sharing [7]. One of the foundations followed by social development is resource, and the development of tourist industry also depends on resource, including natural, cultural, social and labor resource. Among them, the most powerful and sustainable labor resource will determine the direction of tourism in the future. In present's industrial environment, the development thinking of "tourism plus" requests integration and inter-discipline, so higher vocational tourism talents cultivation should adjust cultivation mode, expand professional foundation, enhance the proportion of general education curriculum, intensify the cultivation of vocational ability, improve the level of practice and training, strengthen periodic connection, cultivate interdisciplinary talents with wide vocational knowledge basis, perfect operational skill, and high-level management ability, and enhance the sustainability of employment and growth space of talents. So, school need to making teaching plans and curriculum that have cross-border thinking, and cross-border education is the beginning and end of cultivation of tourism talents. Cross-border education will gradually become an important branch of learning social educational system and college education. And it also gradually becomes the main mode of talent training. Through the implementation of the conception and model about cross-border education, we can cultivate mixed mode talents who can meet the tourism industry development and requirements. What's more, the conception of cross-border learning and blended learning are rooted in talents training. Under the conditions that horizon is equal to boundary, cross-border broaden your horizon. Making tourism combines others are extend tourism boundary infinitely. Therefore, in the development of tourism boundaryless, the best educational direction of the cultivation of tourism talents in higher vocational school is transboundary inter-disciplinary talent.

\section{Explore the new mode of creating demands by producing in the context of "mass entrepreneurship and innovation",}

In the context of mass entrepreneurship and innovation and increasingly prominent comprehensive features of tourist industry, higher demands for innovative spirit and entrepreneurship of tourism talents are put forward in China. In the future, tourism practitioners should be able to recognize, adapt to, serve and lead new industrial condition. At present, the mode of cultivating talents in higher vocational colleges and industry is the planning mode of determining production according to demands rather than the leading mode of promoting demands by producing. However, the major and curriculum are set according to the existing standard and mode, and lack leading advantage, innovation and guidance. Therefore, it is difficult to create substantial new demands under the traditional cultivation mode. Innovating demands means to stimulate and lead consumers to produce demands 
rather than determine production with demands and produce the products needed by consumers, which desperately needs innovative talents. Talents cultivation in innovative industrial condition can lead industrial development and innovation, break the ceiling, tear down the wall, expand innovative space, enhance supply, and lead new consumption demands.

\section{CONCLUSIONS}

In the context of universal tourism, considering the conception of combine tourism with others, internet with others, the supply side of tourism needs to reform. The demand for talents in tourism industry is more and more complex. Tourism industry tends to need people with comprehensive quality and cross-border professional knowledge and skills. This is the new requirement for cultivation of tourism talents. Higher vocational school, as the backbone power to train tourism industry talents, exist currently some problems in the supply of tourism vocational education. There is a pressing need to reform and innovation for cultivation pattern. Only if adjust the plan of training the talented person, can we train more innovative , compound, artisan and high-end skilled tour talents that tourism sector needs.

\section{REFERENCES}

[1] Guo Jing. Connotation and Path of Supply-side Structural Reform of Vocational Education, Chinese Vocational and Technical Education, 2016.27.

[2] Zhang Tao. Development of Higher Vocational Tourism Major in the Context of Region-based Tourism, Modern Education Management, 2016.12.

[3] Yin Baoqing. Supply-side Structural Reform of Vocational Education in New Normal, Vocational \& Technical Education Forum, 2016.19.

[4] Luo Shumei. Reform of Higher Vocational Tourism Curriculum in the Context of Region-based Tourism, Weekly Examination, 2016 (56).

[5] Wang Qiuye. Exploration of Inheritance and Cultivation Path of "Craftsman's Spirit" of Higher Vocational Students in the Context of Supply-side Structural Reform, Estate and Science Tribune, 2016.20.

[6] Kong Baogen. Implementing Method for Cultivating "Craftsman's Spirit" by Higher Vocational Colleges, Journal of Ningbo University(Educational Science Edition), 2016.5.

[7] Zhang Sumei. Status Analysis of Chinese Tourism Education and Countermeasures in the Context of Region-based Tourism, University Education, 2016.12. 